\title{
Want, need and habit as drivers of smoking behaviour: a preliminary analysis
}

\author{
Luis Wehbe ${ }^{1}$, Harveen Kaur Ubhi ${ }^{2}$, Robert West ${ }^{2,3}$
}

${ }^{1}$ Instituto Ave Pulmo, Fundación Enfisema, Mar del Plata, Argentina

${ }^{2}$ Cancer Research UK Health Behaviour Research Centre, University College London, London WC1E 6BT, UK

${ }^{3}$ National Health Service Centre for Smoking Cessation and Training, University College London, London, UK

Competing interests: LW and HKU declare no competing interests. RW undertakes consultancy and research for, and receives travel funds and hospitality from, manufacturers of medications for smoking cessation.

\section{Corresponding Author:}

Harveen Kaur Ubhi, Ph.D.

Cancer Research UK Health Behaviour Research Centre, University College London, London WC1E 6BT, UK

Email: harveenk26@gmail.com

Phone: +44 7891340056 


\section{Abstract}

Background and aims: Models of tobacco smoking behaviour propose that anticipated pleasure or satisfaction, the need to alleviate a nicotine-induced drive state and a stimulus-driven impulse potentially play an important role. This study aimed to provide a preliminary assessment of how far urges to smoke are reported by smokers and whether the strength of such urges prior to a quit attempt predicts short-term success at quitting.

Methods: In a prospective study, 566 smokers attending a treatment programme to help smokers quit completed a written questionnaire covering frequency of different types of urge to smoke (automatic impulse - 'automatic urges', anticipated pleasure - 'pleasure urges', and fulfilling a need - 'need urges'). They were asked to rate this for whichever of these urges was dominant for them. The questionnaire also assessed daily cigarette consumption, time to first cigarette of the day, age and gender. Carbon monoxide verified smoking status was recorded at 1 and 4 weeks after the target quit date.

Findings: A total of $47.9 \%$ (271) of smokers reported that automatic urges were dominant, $21.7 \%$ (123) reported pleasure urges to be dominant, and $30.4 \%$ (172) reported need urges to be dominant. The strength of automatic urges predicted abstinence at both 1 week $(\mathrm{OR}=0.74, \mathrm{p}=0.005,95 \% \mathrm{Cl}=0.60-0.92)$ and 4 weeks $(\mathrm{OR}=0.73, \mathrm{p}=0.008,95 \% \mathrm{Cl}=0.59-0.92)$. Associations between other urge types and abstinence were not statistically significant.

Conclusions: A substantial proportion of smokers attending a clinic for help with quitting report that their dominant urges to smoke occur without any anticipation of pleasure or relief and the strength of the automatic urges predicts failure to sustain abstinence following a quit attempt.

Keywords: smoking cessation, cravings, urge to smoke, PRIME theory of motivation, absent-minded urges, automatic urges. 


\section{Introduction}

Various psychological models of smoking behaviour propose that anticipated pleasure or satisfaction, the need to alleviate an abstinence-induced drive state and cue-driven impulses to smoke all potentially play an important role in people continuing to smoke $(1,2)$. The subjective experience of these has been characterised as the urge to smoke, and the strength of these urges to smoke has been found to be negatively associated with the ability to remain abstinent during a quit attempt $(1,3-5)$. We do not know how prominent specific types of urge are, or whether the strength of these specific urges predicts a relapse following a quit attempt. This paper aimed to address these issues.

A widely used model proposes that smoking urges arise from two sources: reflective processes involving beliefs about consequences, and automatic processes arising from overlearned habits (6). A key aspect of this model is that, through repetition, smoking becomes strongly automatic and the experience of urges arises when the behaviour is blocked, either through conscious restraint or for some other reason. These automatic urges are distinguished from urges arising out of beliefs about the consequences of smoking in terms of pleasure or the functions that smoking may provide. This idea has been elaborated upon and placed within a broader theory of motivation, the PRIME theory $(2,7)$. The PRIME theory (Plans, Responses, Impulses and Inhibitions, Motives and Evaluations) differentiates beliefs about positive and negative consequences ('evaluations') from feelings of attraction and aversion: specifically, feelings of 'want' (feelings of anticipated pleasure or satisfaction) and 'need' (feelings of anticipated relief from, or avoidance of, discomfort or a drive state) $(2,7)$. PRIME also embodies the concept of 'automaticity' in the concept of 'impulses', which may arise from learned associations (habit) or unlearned associations (instinct) with environmental triggers. In this theory, the experience of urges to smoke can arise from wants, needs or automatic impulses. Thus, urges may arise from anticipation of pleasure or satisfaction relief from an unpleasant experience or a drive state, or from a direct association between smoking cues and the impulse to smoke $(2,7)$.

It is unknown which, if any, of the different types of urge dominate in terms of prevalence, and whether these different types of urge have different implications in terms of relapse. This study assessed the prevalence of the different types of urge in a sample of smokers seeking help with a quit attempt, and assessed associations between the strength of different types of urge and the ability to achieve short-term abstinence. 


\section{Methods}

Design

This was a prospective, observational study.

\section{Participants}

Smokers were all attendees at a smokers' clinic in Argentina between October 2008 and March 2011. The clinic treated smokers who wanted help with stopping smoking. They were all aged 21 or over and were smoking at least five cigarettes per day.

\section{Procedure}

The participants attended an initial session while they were smoking. During this initial session, they were encouraged by a trained smoking cessation counsellor to set a target quit date and those who had set a quit date were followed up for 4 weeks after this date.

\section{Measures}

Measures were taken via a self-report questionnaire at the initial visit (baseline), and then at 1 and 4 weeks after the target quit date. The baseline self-report questionnaire asked smokers to identify which of three types of urge to smoke were dominant for them and then to rate the typical strength of these urges on a 6-point scale from no urges to extremely strong urges (Appendix 1, Table A). The scale was translated from a validated scale used in population-level and clinical research in the UK $(4,8-11)$. If the participants were unable to identify a predominant urge type, then they could specify more than one type of urge. In addition, the questionnaire also assessed daily cigarette consumption, time to first cigarette of the day (12), age and gender.

At weeks 1 and 4, the participants reported whether they had smoked at all since the target quit date. Expired-air carbon monoxide concentration was used to confirm abstinence with a threshold of 10 parts per million (ppm) (13-16). The threshold of $10 \mathrm{ppm}$ was used because previous research has shown that this threshold provides very similar results to use of lower thresholds except when these are below $5 \mathrm{ppm}$ at which point they appear to lose accuracy (14).

\section{Analysis}

Means \pm standard deviations (SD), proportions and 95\% confidence intervals ( $\mathrm{Cl}$ ) were used to describe the sample. Pearson's correlations and ANOVAs were used to determine the relationship 
between different types of urge to smoke (automatic urges, pleasure urges and need urges) and other baseline variables. Logistic regression analyses were used to determine the associations between the strength of different types of urge and success at 1 week and 4 weeks. The level of significance was set at $p<0.05$, 2-tailed.

\section{Results}

A total of 566 participants were included in the study. Of these, 294 (51.6\%) were women. The mean age of the participants was 51.8 years (SD 12.5) and the mean cigarette consumption per day was 24.4 (SD 10.4). Over half ( $n=372,65.8 \%)$ of the smokers reported smoking their first morning cigarette within 30 minutes of waking, while $23.5 \%(n=194)$ reported smoking within 5 minutes of waking. A total of $271(47.9 \%)$ smokers reported that automatic urges were dominant, $123(21.7 \%)$ reported pleasure urges to be dominant and $172(30.4 \%)$ reported need urges to be dominant (Table 1$)$. Only 20 smokers identified more than one urge type.

At baseline, the three types of urge to smoke were significantly and positively correlated to the number of cigarettes smoked per day (automatic urges $r=0.30, p<0.001$; pleasure urges $r=0.27$, $p=0.011$; need urges $r=0.33, p<0.001$ ) but were not significantly related to age (automatic urges $r=0.01$, $p=0.864$; pleasure urges $r=-0.1, p=0.290$; need urges $r=-0.02, p<0.779)$. Significant associations were observed between the different types of urge experienced and smokers who reported smoking their first cigarette of the day within 30 minutes of waking (automatic urges: $F(1,269)=27.9, p<0.001$; pleasure urges: $F(1,119)=8.9, p=0.004$; need urges: $F(1,169)=8.1, p=0.005)$, while no significant associations were observed between the different types of urge experienced and gender (Table 2).

The strength of automatic urges negatively predicted abstinence at both 1 week (Odds Ratio $(O R)=0.74, p=0.005,95 \% \mathrm{Cl}=0.60-0.92)$ and 4 weeks $(\mathrm{OR}=0.73, \mathrm{p}=0.008,95 \% \mathrm{Cl}=0.59-0.92)$. Associations between other urge types and abstinence (at 1 week and 4 weeks) were not statistically significant (pleasure urges at 1 week: $\mathrm{OR}=0.86, p=0.393,95 \% \mathrm{Cl}=0.61-1.21$ and 4 weeks: $\mathrm{OR}=0.89, p=0.526$, $95 \% \mathrm{Cl}=0.61-1.29$; and need urges at 1 week: $\mathrm{OR}=0.89, \mathrm{p}=0.407,95 \% \mathrm{Cl}=0.68-1.17$ and 4 weeks OR:0.82, $\mathrm{p}=0.205,95 \% \mathrm{Cl}=0.60-1.12)$.

\section{Discussion}

When smokers were asked to identify their dominant urge type ahead of a quit attempt, those attending a smokers' clinic predominantly reported that these urges were 'automatic', occurring without anticipated pleasure or relief from discomfort. The strength of the automatic urge was negatively associated with their ability to sustain abstinence up to 4 weeks following initiation of a quit attempt. 
Other types of urge - 'pleasure' urges and 'need' urges - were less common and did not significantly predict abstinence.

These findings represent a preliminary assessment of urges classified according to automatic impulses, needs and wants, and suggest that smokers can make this differentiation and that it may be useful in understanding the relapse process. If the pattern of results is replicated, it may provide a more discriminating assessment of smoking motivation, which could be used as a target for aids to smoking cessation. These findings also support a model of smoking behaviour that distinguishes between habitual and goal-focused smoking motives. Relapse is considered to be a major concern in smoking cessation treatment (17-19). Thus, classifying urges prior to a quit attempt could help predict which smokers are prone to the risk of relapse. The findings of this study would be extremely beneficial for smoking cessation counsellors who could identify smokers who are susceptible to relapse; as a result, they could prevent these smokers from relapsing by offering them additional or intensive support. The demographic variables age and gender were not associated with the types of urge in a sample of smokers seeking help with their quit attempt. Previous studies have found some demographic variables to be associated with smoking relapse (compared to continued abstinence in former smokers). These demographic variables include younger age $(18,19)$ and being unmarried (19). However, the association of gender to smoking relapse is not found to be consistent $(17,19)$.

While the findings appear to be statistically robust in this sample, it will be important to assess how far they generalise to smokers in other settings and countries. Factors that may limit such generalisability are the fact that the current sample consisted of clients attending a smokers' clinic in Argentina, they were heavier smokers and seeking treatment. In addition, a particular country setting with a particular culture may have also played a role in the results obtained.

In conclusion, a substantial proportion of smokers attending a clinic for help with smoking cessation report that their dominant urges to smoke occur without any anticipation of pleasure or relief and the strength of the automatic urges predicts failure to sustain abstinence following a quit attempt. If this finding is replicated, it can help to inform our understanding of smoking behaviour. 
Table 1 Baseline characteristics of study participants

\begin{tabular}{|l|c|}
\hline \multicolumn{1}{|c|}{ Characteristics } & All participants (N=566) \\
\hline Female, $\mathrm{n}(\%)$ & $51.8(12.5)$ \\
\hline Age in years, mean (SD) & $24.4(10.4)$ \\
\hline Cigarettes smoked per day, mean (SD) & $133(23.5)$ \\
\hline Time to first cigarette of day, $\mathrm{n}(\%)$ & $117(20.7)$ \\
\hline within 5 minutes & $122(21.6)$ \\
\hline $6-15$ minutes & $110(19.4)$ \\
\hline $16-30$ minutes & $84(14.8)$ \\
\hline $31-60$ minutes & $271(47.9)$ \\
\hline $61+$ minutes & $123(21.7)$ \\
\hline Different types of urges experienced, $\mathrm{n}(\%)$ & $172(30.4)$ \\
\hline Automatic urges & \\
\hline Pleasure urges & \\
\hline Need urges & \\
\hline
\end{tabular}

SD: standard deviation 
Table 2 Mean differences between the different types of urges to smoke and time to first cigarette of the day

\begin{tabular}{|l|c|c|c|}
\hline \multirow{2}{*}{} & \multicolumn{3}{|c|}{ Different types of urges to smoke } \\
\cline { 2 - 4 } & Automatic urges & Pleasure urges & Need urges \\
\hline \multicolumn{2}{|l|}{ Time to first cigarette of the day } & $3.1(1.1)$ \\
\hline $\begin{array}{l}\text { Within } 30 \text { minutes } \\
\text { of waking }\end{array}$ & $4.3(1.2)$ & $3.2(1.0)$ & $3.6(1.0)$ \\
\hline $\begin{array}{l}\text { Later than } 30 \\
\text { minutes of waking }\end{array}$ & $3.5(1.0)$ & & \\
\hline
\end{tabular}

All values represent mean ( \pm standard deviation) 


\section{References}

1. Shiffman S, Gwaltney CJ, Balabanis MH, Liu KS, Paty JA, Kassel JD, et al. Immediate antecedents of cigarette smoking: an analysis from ecological momentary assessment. Journal of abnormal psychology. 2002;111(4):531.

2. West R. The multiple facets of cigarette addiction and what they mean for encouraging and helping smokers to stop. COPD: Journal of Chronic Obstructive Pulmonary Disease. 2009;6(4):277-83.

3. West R, Hajek P. Evaluation of the mood and physical symptoms scale (MPSS) to assess cigarette withdrawal. Psychopharmacology. 2004;177(1-2):195-9.

4. Fidler JA, Shahab L, West R. Strength of urges to smoke as a measure of severity of cigarette dependence: comparison with the Fagerström Test for Nicotine Dependence and its components. Addiction. 2011;106(3):631-8.

5. Ussher M, Beard E, Abikoye G, Hajek P, West R. Urge to smoke over 52 weeks of abstinence. Psychopharmacology. 2013;226(1):83-9.

6. Tiffany ST. A cognitive model of drug urges and drug-use behavior: role of automatic and nonautomatic processes. Psychological review. 1990;97(2):147.

7. West R, Brown J. Theory of addiction: John Wiley \& Sons; 2013.

8. Fidler JA, West R. Enjoyment of smoking and urges to smoke as predictors of attempts and success of attempts to stop smoking: a longitudinal study. Drug and alcohol dependence.

2011;115(1):30-4.

9. Kotz D, Brown J, West R. 'Real-world'effectiveness of smoking cessation treatments: a population study. Addiction. 2014;109(3):491-9.

10. Brose LS, Hitchman SC, Brown J, West R, McNeill A. Is the use of electronic cigarettes while smoking associated with smoking cessation attempts, cessation and reduced cigarette consumption? $\mathrm{A}$ survey with a 1-year follow-up. Addiction. 2015;110(7):1160-8.

11. Riaz M, Lewis S, Coleman T, Aveyard P, West R, Naughton F, et al. Which measures of cigarette dependence are predictors of smoking cessation during pregnancy? Analysis of data from a randomized controlled trial. Addiction. 2016.

12. Kozlowski LT, Porter CQ, Orleans CT, Pope MA, Heatherton T. Predicting smoking cessation with self-reported measures of nicotine dependence: FTQ, FTND, and HSI. Drug and alcohol dependence. 1994;34(3):211-6.

13. West R, Hajek P, Stead L, Stapleton J. Outcome criteria in smoking cessation trials: proposal for a common standard. Addiction. 2005;100(3):299-303.

14. Brose LS, Tombor I, Shahab L, West R. The effect of reducing the threshold for carbon monoxide validation of smoking abstinence-Evidence from the English Stop Smoking Services. Addictive behaviors. 2013;38(10):2529-31.

15. Shahab L. Why use CO-verified 4-week quit rates as the primary measure of stop smoking service success? National Centre for Smoking Cessation and Training (NCSCT). 2014. Link: http://discovery.ucl.ac.uk/1450797/1/Shahab CO-verified 4WQ.pdf (accessed on 9th November, 2016). 16. Brose LS, West R, McDermott MS, Fidler JA, Croghan E, McEwen A. What makes for an effective stop-smoking service? Thorax. 2011;66(10):924-6.

17. McWhorter WP, Boyd GM, Mattson ME. Predictors of quitting smoking: the NHANES I followup experience. Journal of clinical epidemiology. 1990;43(12):1399-405.

18. Augustson EM, Wanke KL, Rogers S, Bergen AW, Chatterjee N, Synder K, et al. Predictors of sustained smoking cessation: a prospective analysis of chronic smokers from the alpha-tocopherol Betacarotene cancer prevention study. American Journal of Public Health. 2008;98(3):549-55. 
19. Herd N, Borland R, Hyland A. Predictors of smoking relapse by duration of abstinence: findings from the International Tobacco Control (ITC) Four Country Survey. Addiction. 2009;104(12):2088-99. 


\section{Funding and Acknowledgements}

The study was funded by the Emphysema Foundation, Argentina. The funders played no role in the design, conduct or analysis of the study, nor in the interpretation and reporting of the study findings. The researchers were independent from the funders.

LW and RW designed the study. HKU wrote the first draft and conducted the analyses. All authors provided significant input in redrafting the manuscript. All authors contributed to and have approved the final manuscript. All authors had full access to all of the data (including statistical reports and tables) in the study and can take responsibility for its integrity as well as the accuracy of the data analysis. 


\section{Appendix 1}

Table A The study questionnaire

Hoja No 2- Semana previa (Questionarire № 2 Week before)

Nombre y Apellido (Name and Surname):

\begin{tabular}{|l|l|l|l|l|l|}
\hline $\begin{array}{l}\text { 1. Depresión o angustia } \\
\text { (Depressed) }\end{array}$ & $\begin{array}{l}\text { Nunca } \\
\text { (Never) }\end{array}$ & $\begin{array}{l}\text { Leves } \\
\text { (Slightly) }\end{array}$ & $\begin{array}{l}\text { Moderadas } \\
\text { (Moderately) }\end{array}$ & $\begin{array}{l}\text { Muchas } \\
\text { (A lot/ } \\
\text { very) }\end{array}$ & $\begin{array}{l}\text { Extremadamtente } \\
\text { (Extremely) }\end{array}$ \\
\hline $\begin{array}{l}\text { 2. Irritable o de mal humor } \\
\text { (Irritable) }\end{array}$ & Nunca & Leves & Moderadas & Muchas & Extremadamente \\
\hline $\begin{array}{l}\text { 3. Inquietud } \\
\text { (Restless) }\end{array}$ & Nunca & Leves & Moderadas & Muchas & Extremadamente \\
\hline $\begin{array}{l}\text { 4. Mas hambre de lo usual } \\
\text { (More hungry than usual) }\end{array}$ & Nunca & Leves & Moderadas & Muchas & Extremadamente \\
\hline $\begin{array}{l}\text { 5. Dificultad de } \\
\text { concentración (Poor } \\
\text { concentration) }\end{array}$ & Nunca & Leves & Moderadas & Muchas & Extremadamente \\
\hline
\end{tabular}

6. ¿Que cantidad de tiempo ha sentido urgencias por fumar en las últimas 24 horas?

(How much of the time have you felt the urge to smoke in the past 24 hours?)

Permanentemente (All the time)

Casi permanentemente (Almost all the time)

Muy frecuentemente (Very frequently)

Frecuentemente (Frequently)

Pocas veces (Sometimes)

Nunca (Never)

7. - ¿Como han sido esas urgencias por fumar?

(How strong have the urges been?)

Extremadamente intensas (Extremely strong) 
Muy intensas (Very strong)

Intensas (Strong)

Moderadas (Moderate)

Leves (Slight)

No he tenido (No urges)

8. ¿Del 0 al 10 cuanto se siete confiado para dejar de fumar?

(From 0 to 10, how confident do you feel about quitting this time?)

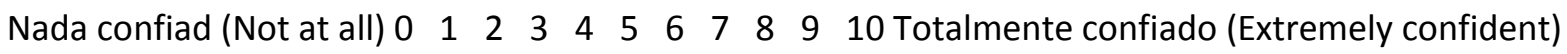

9. ¿Con que frecuencia la urgencia por fumar le viene aún si usted no está pensando en fumar?

(How often does the urge to smoke come to you even though you were not thinking about smoking?)

Nunca (Never)

Pocas veces (A few times)

A menudo (Frequently)

Bastante tiempo (Very frequently)

Casi todo el tiempo (Almost all the time)

Todo el tiempo (All the time)

10. ¿Con que frecuencia usted piensa en lo placentero que sería fumar un cigarrillo?

(How often do you think about how pleasant it would be to smoke a cigarette?

Nunca (Never)

Pocas veces (A few times)

A menudo (Frequently)

Bastante tiempo (Very frequently)

Casi todo el tiempo (Almost all the time)

Todo el tiempo (All the time)

11. ¿Con que frecuencia usted tiene necesidad de fumar un cigarrillo para aliviar lo que usted siente casi como "hambre" por un cigarrillo?

(How often do you have a need to smoke to relieve what feels to you almost like a 'hunger' for a cigarette?) 
Nunca (Never)

Pocas veces (A few times)

A menudo (Frequently)

Bastante tiempo (Very frequently)

Casi todo el tiempo (Almost all the time)

Todo el tiempo (All the time)

12. $\mathrm{CO}:$ . ppm 